\title{
Analysis of Optimal Portfolio Formation Using Single Index Model and Stochastic Dominance on Sri-Kehati Index
}

\author{
Samsul Huda and Pardomuan Sihombing
}

\section{ABSTRACT}

\begin{abstract}
This study directly applies the Single Index Model and Stochastic Dominance to solve the portfolio selection problem. This study aims to determine the difference in performance between the Single Index Model and Stochastic Dominance. The use of secondary data was used in this study by selecting the sample using the purposive sampling technique. If viewed based on the portfolio return, the single-index model can produce a portfolio return of $(1.548 \%)$ and a stochastic dominance return of $(0.888 \%)$. The results show that the value of the Stochastic Dominance portfolio formation has a Treynor index which is $\mathbf{2 . 2 2 \%}$ higher than the Single Index Model with a Treynor index of $2.09 \%$.
\end{abstract}

Keywords: Optimal Portfolio, Single Index Model, Stochastic Dominance.

\author{
Submitted : January 11, 2022 \\ Published : February 05, 2022 \\ ISSN: 2507-1076 \\ DOI: $10.24018 /$ ejbmr.2022.7.1.1264 \\ Samsul Huda * \\ Mercu Buana University, Jakarta, Indonesia. \\ (e-mail: eshakom@gmail.com) \\ Pardomuan Sihombing \\ Mercu Buana University, Jakarta, Indonesia \\ (e-mail: \\ pardomuan.sihombing@mercubuana.ac.id) \\ *Corresponding Author
}

\section{INTRODUCTION}

Investment has a role in improving the economy of a country because investment is one component of aggregate expenditure in the calculation of national income. Investments can be made in real assets in the form of buildings, land, and gold, while financial assets in the form of stocks and bonds.

Stocks are one of the most desirable investment alternatives because stocks can provide benefits in the form of dividends and capital gains. In stock investment, the profits received by investors are called returns which are divided into two, namely expected returns and realized returns. However, in addition to providing returns, stocks also contain risks that must be borne by investors.

The greater the risk borne, the greater the return that is compensated, the risk in investment makes investors have to do the right ways to minimize the risks that may occur. Investors do not know for sure the results that will be obtained so investors need to diversify to reduce risk.

In investing, investors do not stop at diversification to reduce risk, but also investors want optimal returns from their investments. In selecting the optimal portfolio, investors can use several models of financial analysis. The research in this study reviews two methods used in forming an optimal portfolio, namely: Single Index Model and Stochastic Dominance.

Stochastic dominance is a technique that does not pay attention to how the distribution of the level of return on investments is being considered. In other words, stochastic dominance does not require the distribution of profit levels to be normal. Stochastic dominance uses three assumptions, namely first order, second order and third order. First-order stochastic dominance states that investors prefer a lot to a little. Second-order stochastic dominance states that investors are risk-averse. While the third-order stochastic dominance states that investors have decreasing absolute risk aversion (Ningrum et al., 2018).

Optimal portfolio testing using the single index model method (single index) has proven that this model makes it possible to obtain optimal stock portfolio performance. Based on the results of a study conducted by Achmad Khotim (Khotim \& Topowijono, 2014) stated that there is a significant difference in portfolio returns using the Single Index Model or using Stochastic Dominance. The results of the optimal portfolio formation from the Single Index Model show that the expected return is higher than the optimal portfolio expected return using Stochastic Dominance. While the results of a study conducted by Wulandari (Putu et al., 2016) stated the opposite, namely the results of forming an optimal portfolio using Stochastic Dominance showed a higher expected return than the optimal expected return of a portfolio using the Single Index Model. The results of these calculations indicate that the risk of the portfolio is smaller than the risk of the stock before the portfolio. This shows that forming an optimal portfolio can reduce the amount of risk.

From various backgrounds and contradictory findings regarding the differences in the use of the Single Index Model and Stochastic Dominance in determining the optimal portfolio in the previous study, the author is interested in reinvestigating the comparison of the two methods using the Sri-Kehati index.

The selection of the Sri-Kehati index as a study of the increasing number of investment product indexes as an investment guide that is widely used by investors in determining their investment decisions (kontan.co.id, 14April-2019) since the beginning of the year the Sri-Kehati 
index has increased by $4.68 \%$ greater than the JCI which increased by $3.41 \%$. This shows that the Sri-Kehati index has a fairly good performance and deserves to be used as an alternative investment for investors.

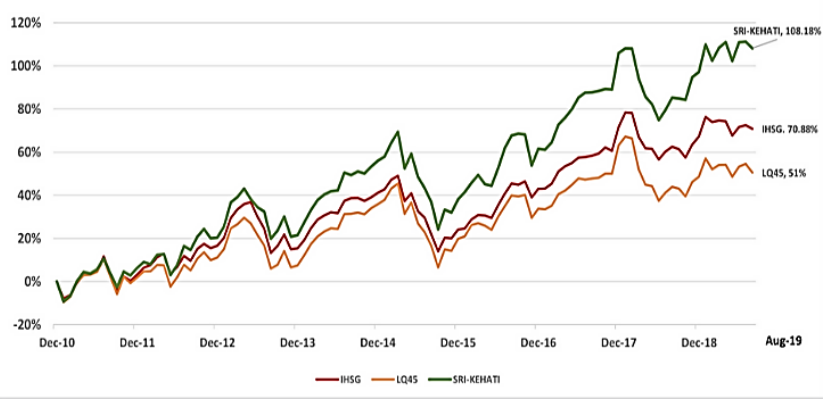

Fig. 1. Chart Index Sri-Kehati Period 2010-2019.

Looking at the picture above, it can be seen that that the Sri-kehati index experienced a higher increase than the JCI and LQ45 indexes. So, the authors decided in this study to examine Sri-Kehati stocks listed on the IDX during the period January 2017 - December 2021.

\section{LITERATURE REVIEW}

\section{A. Portfolio Theory}

Portfolio theory was first introduced by Markowitz (1952). This model will produce a portfolio through a process based on the mean variance. The mean is the expected return which is mostly calculated by means of an average and the variance is a measure of risk used. Markowitz's model of portfolio theory teaches investing by breaking down the invested funds, which is called then putting them on different paths, instead of focusing on only one path or called diversification. The separate placement of funds is intended to reduce the risks that will arise in the future which will give birth to the Efficient Frontier.

Portfolio is a field of science that examines how an investor can reduce risk in investing to a minimum, including one of them by diversifying these risks (Fahmi, 2015). By forming a portfolio to maximize the expected return at the level of risk borne by investors, the index model or factor model assumes that the rate of return of a security is sensitive to changes in various factors or indices. As a process of calculating the rate of return, an index model seeks to include the main economic forces that can systematically move stock prices for all securities (Hadar \& Russell, 1971).

\section{B. Efficient and Optimal Portfolio}

According to Pardomuan, an efficient portfolio is a portfolio that has a maximum return at each level of risk. The efficient portfolio dominates all other portfolios. The dominant portfolio offers a maximum return for a certain level of risk or vice versa, a minimum risk for a certain return (Sihombing, 2018).

An efficient portfolio only has one good factor, namely the expected return or portfolio risk, so it has not combined the two. The optimal portfolio is selected from the efficient portfolio members. Hartono (Hartono, 2015) explains that an efficient portfolio is a portfolio that provides the largest expected return with a certain risk or provides the smallest risk with a certain expected return. An optimal portfolio is an efficient portfolio, but an efficient portfolio is not necessarily an optimal portfolio.

\section{Single Index Model}

The Single Index Model was developed by William Sharpe, an American economist in 1963. This model can be used to simplify calculations on the Markowitz model. The Single Index Model is based on the observation that the price of a security fluctuates in the direction of the market price index. Stocks in general will experience an increase in price if the stock price index rises and vice versa the price of most stocks will decrease if the stock price index falls.

Hartono (2016: 427) explains that the single index model is based on the observation that the price of a security fluctuates in the direction of the market price index. The model assumes that the movement of stock returns is only related to market movements. The Single Index Model divides the return from securities into two parts, namely the unique return component represented by $i$ which is independent of market returns, and the return component associated with market returns represented by $\beta i$.

\section{Stochastic Dominance}

Stochastic dominance was developed by Hadar and Russell (1971). Decision-making theory faces uncertainty, a company usually aims to maximize the expected value of the utility function (expected utility), a certain objective function set by the company based on the choice of existing conditions. Suppose there are two choices of conditions, A and $\mathrm{B}$, then condition $\mathrm{A}$ will be preferred over condition $\mathrm{B}$ if and only if the expected utility value of A is higher or equal to the expected value of B's utility (Hadar \& Russell, 1971).

Stochastic dominance is a technique that does not pay attention to how the distribution of the level of return on investments is being considered. In other words, stochastic dominance does not require the distribution of profit levels to be normal. Stochastic dominance is applied to overcome problems regarding the selection and evaluation of stock and portfolio investments, due to the weakness of economic theory in providing predictions or future descriptions of investor preferences and profit distribution (Ningrum et al., 2018).

\section{E. Return and Risk Investation}

According to Fahmi, return is the profit obtained by companies, individuals, and institutions from the results of their investment policies. Return or return on investment is income (gain) or loss (loss) due to a decrease in investment value in a certain period. Return is the result obtained from the investment (Fahmi, 2015).

The expected rate of return is a weighted average of the expected rate of return on the assets in the investment. The weight reflects the fraction of the total invested in each asset (Sihombing, 2018).

Risk according to Fahmi risk can be interpreted as a form of uncertainty about a situation that will occur later (future) with decisions taken based on various considerations at this time, risk is the amount of deviation between the expected return and the level of risk. actual return. The greater the occurrence of deviations, the greater the level of risk(Fahmi, 2015). 


\section{RESEARCH METHOD}

The type of research in this research is descriptive with a quantitative approach. The quantitative approach gives freedom to researchers to determine various criteria or variables to be studied.

The population is also a collection of objects or subjects that meet the characteristics that the researcher wants to study and then draw a conclusion. The population used in this study is the shares of companies registered in Sri-Kehati from January 2017 to December 2021.

Sri-Kehati Index data was obtained from the closing price of the Index from January 2017 to December 2021. Data obtained from www.finance.yahoo.com

Data Suku Bunga Indonesia (SBI) was obtained from www.bi.go.id in the period January 2017 - December 2021. Indonesia's interest rate data is a reference for risk-free returns or as a risk-free rate.

Data analysis uses two analytical models, namely the single index model and the stochastic dominance model. The analysis using a single index model is to calculate the realized return value ( $\mathrm{Ri}$ ) of each stock every month, calculate the expected return $(\mathrm{E}(\mathrm{Ri}))$ of each stock, calculate the market return (RM) for the period January 2017 - December 2021, calculate the expected return. market $(\mathrm{E}(\mathrm{RM}))$, calculate the covariance $\mathrm{Ri}$ and $\mathrm{RM}$, calculate market variance ( $\sigma \mathrm{M} 2$ ), calculate the beta of the $i$-th stock $(\beta i)$, determine the risk-free rate of return (RBR) using the average $\mathrm{BI}$ rate for the period January 2017 - December 2021, calculate $i$ for each stock, calculate residual error (residual error), calculate residual error variance for $\mathrm{i}$-stock, calculate the excess return to beta (ERBi), calculate Ai for each i-share, calculate Bi for each each $i$-th stock, calculates the cut off rate $(\mathrm{Ci})$, calculates $\mathrm{Zi}$ and $W i$ and calculates the return of the portfolio formed by the single index model.

Analysis of optimal portfolio formation with stochastic dominance through several stages of data analysis, namely calculating the realized return value $(R i)$ of each stock every month, sorting stocks based on the smallest return value to the largest return value (in ascending sort), determining all pairs stocks that may occur, determine the probability for each stock, calculate first-order stochastic dominance, calculate second-order stochastic dominance (if there is no stochastic dominance of the pair between stocks in the first order), calculate third-order stochastic dominance (if there is no stochastic dominance of the pair) between stocks in the second-order), making decisions regarding stochastic dominance in stock pairs, recording the results of stochastically dominant and non-stochastically dominant pairs between stocks, determining the proportion of shares (Wi) for optimal portfolio stock candidates and calculating returns on stock. of the optimal portfolio formed.

The difference test is also known as a comparison test, where both compare the results of the research sample whether there is a significant difference from the results of the study. The different test used in this study is the Treynor index method.

\section{RESUlt AND Discussion}

In calculating returns from individual stocks, the first thing to look for is the return value each month by dividing last month's closing price divided by the current month's closing price and then dividing by last month's closing price, after the monthly return value is obtained.

$$
R_{i t}=\frac{P_{i t}-P_{i t-1}}{P_{i t-1}}
$$

Sources: Hartono (2016)

Next, calculate the average return value for 60 months to determine the value of $E(R i)$, where stocks that have a negative $E(R i)$ value will be eliminated.

$$
E\left(R_{i}\right)=\frac{\sum R t_{i}}{n}
$$

Sources: Hartono (2016)

So, after doing this calculation, the previous sample of 15 stocks decreased to 10 stocks because there were 5 stocks that had a negative $E(R i)$ value.

\begin{tabular}{|c|c|c|c|}
\hline No & Issuer & Company profile & $E\left(R_{i}\right)$ \\
\hline 1 & ASII & Astra International Tbk. & $-0,0020647$ \\
\hline 2 & $\mathrm{BBCA}$ & Astra International Tbk & 0,0159941 \\
\hline 3 & $\mathrm{BBNI}$ & $\begin{array}{l}\text { Bank Negara Indonesia } \\
\text { (Persero) Tbk. }\end{array}$ & 0,0095438 \\
\hline 4 & BBRI & $\begin{array}{l}\text { Bank Rakyat Indonesia } \\
\text { (Persero) Tbk }\end{array}$ & 0,0125589 \\
\hline 5 & BMRI & Bank Mandiri (Persero) Tbk. & 0,0074833 \\
\hline 6 & BSDE & Bumi Serpong Damai Tbk. & $-0,0053916$ \\
\hline 7 & INDF & $\begin{array}{c}\text { Indofood Sukses Makmur } \\
\text { Tbk. }\end{array}$ & $-0,0017854$ \\
\hline 8 & JSMR & Jasa Marga (Persero) Tbk. & 0,0048208 \\
\hline 9 & KLBF & Kalbe Farma Tbk. & 0,0037653 \\
\hline 10 & PGAS & $\begin{array}{l}\text { Perusahaan Gas Negara } \\
\text { (Persero) Tbk. }\end{array}$ & 0,0028258 \\
\hline 11 & SMGR & $\begin{array}{c}\text { Semen Indonesia (Persero) } \\
\text { Tbk. }\end{array}$ & 0,0028323 \\
\hline 12 & TLKM & $\begin{array}{l}\text { Telekomunikasi Indonesia } \\
\text { (Persero) Tbk. }\end{array}$ & 0,0028505 \\
\hline 13 & UNTR & United Tractors Tbk. & 0,0043538 \\
\hline 14 & UNVR & Unilever Indonesia Tbk. & $-0,0095495$ \\
\hline 15 & WIKA & Wijaya Karya (Persero) Tbk. & $-0,001612$ \\
\hline
\end{tabular}

TABLE I: EXPECTED RETURN OF 15 SAMPLE COMPANIES

\section{A. Single Index Model}

Stocks that are included in the optimal portfolio with a single index model are stocks that have a high excess return to beta (ERB) value, stocks with a low ERB are not included in the portfolio. To be able to determine and calculate ERBi, it is necessary to first calculate market return $(R M)$, market expected return or $E(R M)$, covariance $R i$ and $R M$, market variance, beta of the $i$-th stock $(\beta i)$, determine the risk-free rate of return. (RBR), $i$ for each stock, residual error (residual error), calculating the variance of the residual error of the $i$-th stock

Market return $(\mathrm{Rm})$ is calculated using the Sri-Kehati index stock data. Market return is calculated by the formula:

$$
R_{m(i)}=\frac{X I S R_{t(i)}-X I S R_{t-1(i)}}{X I S R_{t-1(i)}}
$$

Sources: Hartono (2016). 
Calculating the expected return or expected profit rate is by using the following formula:

$$
E\left(R_{m}\right)=\frac{\sum R t_{m}}{n}
$$

Sources: Hartono (2016).

The results of the calculation of the Sri-Kehati Index show a market return of 0.24802 and an expected market return of 0.00413 .

Market variance is the difference between the expected market return and the market return. Market Variance can be calculated by the formula:

$$
=\sum_{i=n}^{n} \frac{\left[\left(R_{t(i)}-E\left(R_{m}\right)\right)\right]^{2}}{n}
$$

Sources: Hartono (2016).

Based on the data that has been processed by researchers, the market variance is obtained at 0.00254 .

Excess return to beta means measuring the excess return relative to beta, where to measure this $E R B$ it is necessary to return risk-free assets. certain. $E R B$ can be calculated by the formula:

$$
E R B=\frac{E\left(R_{i}\right)-R_{f}}{\beta_{i}}
$$

Sources: Hartono (2016).

To determine which stocks, have a high $E R B$ and which stocks have a low $E R B$, it is necessary to set a cutoff rate. The limiting point or cut-off rate $(\mathrm{Ci})$ is used to determine which stocks are then included in the optimal portfolio and which stocks are not included in the optimal portfolio. $\mathrm{Ci}$ will provide an overview of the last point where stocks can still be included in the optimal portfolio.

As for calculating the Cut off rate with the formula:

$$
C_{i}=\frac{\sigma_{m}^{2} \sum_{j=1}^{i} \frac{\left(E\left(R_{i}\right)-R_{f}\right) \beta j}{\sigma_{e i}^{2}}}{1+\sigma_{m}^{2} \sum_{j=1}^{i}\left[\frac{\beta_{i}^{2}}{\sigma_{e i}^{2}}\right]}
$$

Sources: Hartono (2016).

The cut off point $\left(C^{*}\right)$ is the $\mathrm{Ci}$ value where the last ERB value was still greater than the $\mathrm{Ci}$ value. The securities that make up the optimal portfolio are securities that have an ERB value greater than or equal to the ERB value at point $C^{*}$. securities that have a smaller ERB value with an ERB of point $C^{*}$ are not included in the formation of the optimal portfolio.

The shares included in the candidate portfolio will then be determined by the proportion of funds for each share in the optimal portfolio. The proportion of funds can be calculated by the following formula:

$$
\begin{gathered}
Z_{i}=\frac{\beta i}{\sigma e i 2}(E R B i-C *) \\
W_{i}=\frac{Z i}{\sum Z}
\end{gathered}
$$

Sources: Hartono (2016).

After knowing the proportion of each stock, then calculate the expected return and the risks, expected return, and optimal portfolio risk.

The shares included in the candidate portfolio will then be determined by the proportion of funds for each share in the optimal portfolio. The proportion of funds can be calculated

\begin{tabular}{|c|c|c|c|c|c|c|c|}
\hline $\mathrm{NO}$ & Emiten & $\mathrm{Wi}$ & $\mathrm{E}(\mathrm{Ri})$ & $\mathrm{E}(\mathrm{Rp})$ & $A p$ & $B p$ & \\
\hline 1 & BBCA & $85,08 \%$ & 0,01599 & $1,3608 \%$ & 0,010593 & 0,729400 & 0,003957 \\
\hline \multirow[t]{7}{*}{2} & BBRI & $14,92 \%$ & 0,01256 & $0,1873 \%$ & 0,001069 & 0,194591 & 0,001560 \\
\hline & & & & $1,5482 \%$ & 0,011662 & 0,923990 & 0,005517 \\
\hline & & & & & & $\mathrm{E}(\mathrm{Rm})$ & 0,00413 \\
\hline & & & & & & $\mathrm{E}(\mathrm{Rp})$ & 0,01548 \\
\hline & & & & & & & $1,55 \%$ \\
\hline & & & & \multicolumn{3}{|c|}{ Variance Market } & 0,00254 \\
\hline & & & & \multicolumn{3}{|c|}{ Variance Portofolio } & 0,00769 \\
\hline
\end{tabular}
by the following formula:

$$
Z_{i}=\frac{\beta \mathrm{i}}{\sigma \mathrm{ei} 2}(\mathrm{ERBi}-\mathrm{C} *)
$$

\begin{tabular}{|c|c|c|c|c|c|c|c|c|}
\hline No. & Emiten & $A$ & $B$ & & ERB & $\mathrm{C}_{\mathrm{i}}$ & $\mathrm{C}^{*}$ & Remarks \\
\hline 1 & $\mathrm{BBCA}$ & 0,01245 & 0,857284 & 0,004651 & 0,014175 & 0,004061 & 0,004061 & OPTIMAL \\
\hline 2 & BBNI & 0,00183 & 1,865414 & 0,021107 & 0,003057 & 0,000902 & 0,004061 & \\
\hline 3 & BBRI & 0,00717 & 1,304459 & 0,01046 & 0,006682 & 0,001954 & 0,004061 & OPTIMAL \\
\hline 4 & BMRI & 0,00224 & 1,269547 & 0,009967 & 0,002868 & 0,000835 & 0,004061 & \\
\hline 5 & JSMR & $-0,00033$ & 1,246912 & 0,015052 & 0,000785 & 0,000163 & 0,004061 & \\
\hline 6 & KLBF & 0,00135 & 0,585314 & 0,004846 & $-0,00013$ & $-0,000020$ & 0,004061 & \\
\hline 7 & PGAS & $-0,00585$ & 2,0976 & 0,036305 & $-0,00048$ & $-0,000114$ & 0,004061 & \\
\hline 8 & SMGR & $-0,00308$ & 1,429341 & 0,018344 & $-0,00071$ & $-0,000156$ & 0,004061 & \\
\hline 9 & TLKM & 0,00016 & 0,650273 & 0,005395 & $-0,00152$ & $-0,000253$ & 0,004061 & \\
\hline 10 & UNTR & 0,00181 & 0,615887 & 0,009498 & 0,000831 & 0,000077 & 0,004061 & \\
\hline
\end{tabular}

From the table above, the single-index model method can produce a return of $1.548 \%$ and a risk of $0.888 \%$.

TABLE II: CALCULATION RESULTS OF OPTIMAL PORTFOLIO CANDIDATES

TABLE III: CALCULATION OF RETURN AND PORTFOLIO RISK 


\section{B. Stochastic Dominance}

After knowing the return value of each stock, the next step is to calculate the probability of each stock. In this study, the observation period was 60 months. The calculation of the probability is obtained by using the formula:

$$
\operatorname{Prob}=\frac{x}{\sum x}
$$

Then the probability value obtained is 0.01667 . Then the individual stock returns and stock probabilities are sorted from the smallest to the largest value.

The next step is to calculate the first assumption, namely the first-order. Stochastic dominance, which means investors prefer a lot to a little. What many here means is the risk of shares that investors will accept, so it can be said that investors like risk. First-order stochastic dominance is calculated by adding up each probability of each stock.

$$
\left[F_{B}(W)-F_{A}(W)\right] \geq 0
$$

(Ningrum et al., 2018).

Because there is no first-order stochastic dominance, then the second-order stochastic dominance assumption is calculated, which means that investors are risk-averse. After calculating the second-order stochastic dominance and the result of the dominance is still unknown, then proceed to the calculation of the third-order stochastic dominance, which means that investors are desiring absolute risk aversion or reducing risk aversion. After calculating the third-order stochastic dominance by adding up the cumulative probabilities of the second-order stochastic dominance until there is no cumulative probability sum that is greater than or equal to the pair of shares being tested.
From the calculation of the assumption of stochastic dominance on 45 stock pairs that have been calculated, the first-order stock dominance is that there is no dominance.

For the second assumption, the second-order stochastic domination is BBCA's dominance over BBNI, BBRI, BMRI, JSMR, KLBF, PGAS, SMGR, UNTR, and TLKM. BBRI dominates BBNI, JSMR, and PGAS. BMRI dominates over BBNI, JSMR and PGAS. KLBF dominates JSMR, PGAS, SMGR, and UNTR. SMGR dominates over PGAS. TLKM dominates over BBNI, JSMR, PGAS, TLKM and UNTR. UNTR dominates over PGAS and SMGR. And the final assumption is that the third-order stochastic dominance is the dominance of KLBF over BBNI.

The results of stochastic dominance in Table IV are used to sort the shares of issuers based on the magnitude of dominance. The stock ranking based on the amount of

\begin{tabular}{|c|c|c|}
\hline No. & Code & Domination \\
\hline 1 & BBCA & 9 \\
\hline 2 & KLBF & 5 \\
\hline 3 & TLKM & 5 \\
\hline 4 & BBRI & 3 \\
\hline 5 & BMRI & 3 \\
\hline 6 & UNTR & 2 \\
\hline 7 & SMGR & 1 \\
\hline 8 & BBNI & 0 \\
\hline 9 & JSMR & 0 \\
\hline 10 & PGAS & 0 \\
\hline \multicolumn{2}{|c|}{ Total } & 28 \\
\hline
\end{tabular}
dominance is presented in the following table:

Next, it is necessary to determine the proportion of funds for each stock in the optimal portfolio and calculate the return and risk of the portfolio.

So, the portfolio return $(R p)$ formed by the stochastic dominance analysis is $0.888 \%$, and the risk is $0.876 \%$.

\begin{tabular}{|c|c|c|c|c|c|c|c|c|c|c|c|c|}
\hline & & & 1 & 2 & 3 & 4 & 5 & 6 & 7 & 8 & 9 & 10 \\
\hline No & Code & & $\mathrm{A}$ & $\mathrm{B}$ & $\mathrm{C}$ & $\mathrm{D}$ & $\mathrm{E}$ & $\mathrm{F}$ & $\mathrm{G}$ & $\mathrm{H}$ & $\mathrm{I}$ & $\mathrm{J}$ \\
\hline 1 & BBCA & A & & & & & & & & & & \\
\hline 2 & BBNI & B & A & & & & & & & & & \\
\hline 3 & BBRI & $\mathrm{C}$ & A & $\mathrm{C}$ & & & & & & & & \\
\hline 4 & BMRI & D & A & D & & & & & & & & \\
\hline 5 & JSMR & $\mathrm{E}$ & A & & $\mathrm{C}$ & D & & & & & & \\
\hline 6 & KLBF & $\mathrm{F}$ & A & $\mathrm{F}$ & & & $\mathrm{F}$ & & & & & \\
\hline 7 & PGAS & G & A & & $\mathrm{C}$ & D & & $\mathrm{F}$ & & & & \\
\hline 8 & SMGR & $\mathrm{H}$ & A & & & & & $\mathrm{F}$ & $\mathrm{H}$ & & & \\
\hline 9 & TLKM & I & A & I & & & I & & I & I & & \\
\hline 10 & UNTR & $\mathrm{J}$ & A & & & & & $\mathrm{F}$ & $\mathrm{J}$ & $\mathbf{J}$ & I & \\
\hline & $\begin{array}{r}\text { Firs } \\
\text { secon } \\
\text { Thir } \\
\end{array}$ & & & & & & & & & & & \\
\hline
\end{tabular}

TABLE IV: RESULTS OF DOMINANCE OF ISSUER SHARES

TABLE VI: CALCULATION OF RETURN AND PORTFOLIO RISK

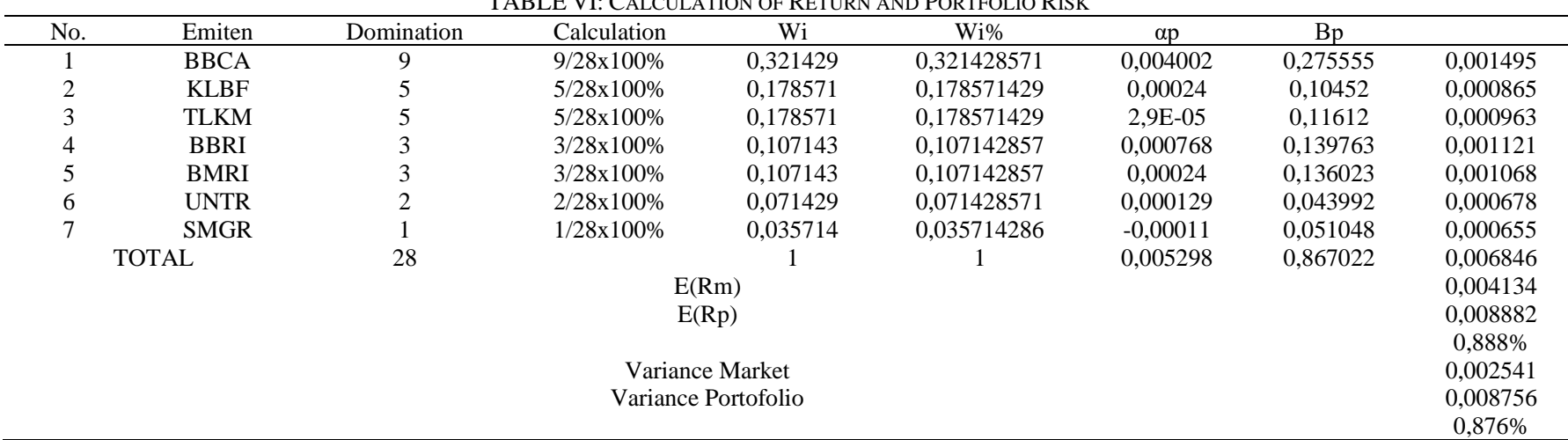




\section{Treynor}

After the expected return and risk of the two methods between the single-index model and stochastic dominance are known, then they are tested with the index Treynor.

TABLE VII: TEST RESULTS WITH TREYNOR INDEX

\begin{tabular}{ccc}
\hline Portfolio & Index Treynor & $\begin{array}{c}\text { Index } \\
\text { Treynor(\%) }\end{array}$ \\
\hline Single Index Model & 0,020857 & $2,09 \%$ \\
Stochastic Dominance & 0,022194 & $2,22 \%$ \\
Market & 0,000292 & $0,03 \%$ \\
\hline
\end{tabular}

The results show that the value of portfolio formation using the Single Index Model has a higher Treynor index of $2.09 \%$ compared to Stochastic Dominance with a Treynor index of $2.22 \%$. This study shows that the performance of a portfolio that is above the securities market line has a performance above the market performance, which indicates that the two methods above can produce an optimal portfolio.

\section{CONCLUSION}

\section{A. Conclusion}

1. In this study, based on the discussion in the previous chapter, the process and results of data using the Single Index Model were able to produce two candidate stock portfolios. The two optimal portfolios are BBCA and BBRI. The result of the calculation of portfolio return for the Single Index Model is $1548 \%$, with a risk of $0.769 \%$.

2. The use of Stochastic Dominance is able to produce seven stocks. The thirteen portfolio stocks are BBCA, KLBF, TLKM, BBRI, BMRI, UNTR, SMGR. The result of the calculation of portfolio return for Stochastic Dominance is $0.888 \%$, with a risk of $0.876 \%$.

3 . The results showed that the value of the Stochastic Dominance portfolio formation had a higher Treynor index of $2.22 \%$ compared to the Single Index Model with a Treynor index of $2.09 \%$. This study shows that the performance of a portfolio that is above the securities market line has a performance above the market performance, which indicates that both can be used as an optimal portfolio.

\section{B. Suggestions}

\section{1) For Investors}

Investors who want to invest in stocks in the capital market can use both methods, namely the Single Index Model and Stochastic Dominance, which can produce an optimal portfolio and the Treynor index above the market, but it is also necessary to consider many things, including the analytical tools used to determine which one to choose. Each analysis tool produces a different stock candidate. Investing in stocks in the capital market, investors should choose the right stocks to include in their portfolios and diversify stocks to reduce the risk of loss. If there is a decrease in the price of one share, the loss can be compensated for by other shares.

\section{2) Further Research}

Some important things from the findings can be suggested based on the limitations of the study, namely the sample that is still below 30, namely as many as 15 stock samples that are consistently included in the Sri-Kehati Index during the period January 2017 to December 2021. The object of research can be carried out outside the Sri-Kehati index. Be careful; apart from using the Treynor Index, the Sharpe Index and the Jensen Index can also be added to the assessment of performance measurement. This is done to compare each performance (Sharpe, Treynor, and Jensen) with two optimal portfolio formation methods, namely Single Index Model and Stochastic Dominance. Based on the limitations of this study, it is recommended for further researchers to analyze the optimal portfolio of research samples plus and the object of research is carried out on stocks whose correlation between securities is perfectly negative. Performance testing can use three indices, namely Sharpe, Treynor, and Jensen, to find out how the differences between each index are.

\section{CONFLICT OF INTEREST}

The authors declare that they do not have any conflict of interest.

\section{REFERENCES}

Fahmi, I. (2015). Pengantar Manajemen Keuangan Teori dan Soal Jawab. Alfabeta.

Hadar, J., \& Russell, W. R. (1971). Stochastic dominance and diversification. Journal of Economic Theory, 3(3), 288-305. https://doi.org/https://doi.org/10.1016/0022-0531(71)90024-X.

Khotim, A., \& Topowijono, D. (2014). Analisis Pembentukan Portofolio Optimal dengan Menggunakan Model Indeks Tunggal dan Stochastic Dominance dalam Pengambilan Keputusan Investasi (Studi Pada Saham-Saham Indeks Sri-Kehati Yang Listing Di Bursa Efek Indonesia Periode 2010-2013). In Jurnal Administrasi Bisnis $(J A B) \mid \operatorname{Vol}$ (Vol. 11, Issue 1). www.detik.com.

Ningrum, E. R., Waskita, J., \& Utami, Y. (2018). Analisis pembentukan portofolio optimal dengan metode stochastic dominance dan single index model pada saham industri real estate and property dibursa efek Indonesia. Permana, 10(1).

Putu, L., Wulandari, F., Sedana, P., \& Anom Purbawangsa, I. B. (2016). kinerja portofolio saham optimal di bursa efek Indonesia (Berdasarkan Single Index Model dan Stochastic Dominance). EJurnal Ekonomi Dan Bisnis Universitas Udayana.

Sihombing, P. (2018). Sihombing, Pardomuan. 2018. Corporate Financial Management. Bogor IPB Science Techno Park. IPB Science Techno Park. 